\title{
CYP2 family: physiological enzymes subset in GtoPdb v.2021.2
}

\author{
Kathryn Burns ${ }^{1}$ and Nuala Ann Helsby ${ }^{1}$
}

1. University of Auckland, New Zealand

\begin{abstract}
Compared to the other CYP2 family enzymes, this subset have physiological rather than drug metabolising enzyme activities.
\end{abstract}

\section{Contents}

This is a citation summary for CYP2 family: physiological enzymes subset in the Guide to Pharmacology database (GtoPdb). It exists purely as an adjunct to the database to facilitate the recognition of citations to and from the database by citation analyzers. Readers will almost certainly want to visit the relevant sections of the database which are given here under database links.

GtoPdb is an expert-driven guide to pharmacological targets and the substances that act on them. GtoPdb is a reference work which is most usefully represented as an on-line database. As in any publication this work should be appropriately cited, and the papers it cites should also be recognized. This document provides a citation for the relevant parts of the database, and also provides a reference list for the research cited by those parts. For further details see [1].

Please note that the database version for the citations given in GtoPdb are to the most recent preceding version in which the family or its subfamilies and targets were substantially changed. The links below are to the current version. If you need to consult the cited version, rather than the most recent version, please contact the GtoPdb curators.

\section{Database links}

CYP2 family: physiological enzymes subset

https://www.guidetopharmacology.org/GRAC/FamilyDisplayForward?familyId=1062

Enzymes

\section{CYP2R1}

https://www.guidetopharmacology.org/GRAC/ObjectDisplayForward?objectId=1333 CYP2S1

https://www.guidetopharmacology.org/GRAC/ObjectDisplayForward?objectId=1334 CYP2U1

https://www.guidetopharmacology.org/GRAC/ObjectDisplayForward?objectId=1335 CYP2W1

https://www.guidetopharmacology.org/GRAC/ObjectDisplayForward?objectId=1336

\section{References}

1. Buneman P, Christie G, Davies JA, Dimitrellou R, Harding SD, Pawson AJ, Sharman JL and Wu Y. (2020) Why data citation isn't working, and what to do about it Database $\mathbf{2 0 2 0}$ [PMID:32367113]

2. Cheng JB, Motola DL, Mangelsdorf DJ and Russell DW. (2003) De-orphanization of cytochrome P450 2R1: a microsomal vitamin D 25-hydroxilase. J Biol Chem 278: 38084-93 [PMID:12867411]

3. Chuang SS, Helvig C, Taimi M, Ramshaw HA, Collop AH, Amad M, White JA, Petkovich M, Jones G and Korczak B. (2004) CYP2U1, a novel human thymus- and brain-specific cytochrome P450, catalyzes omega- and (omega-1)-hydroxylation of fatty acids. J Biol Chem 279: 6305-14 [PMID:14660610] 
4. Chung FF, Mai CW, Ng PY and Leong CO. (2016) Cytochrome P450 2W1 (CYP2W1) in Colorectal Cancers. Curr Cancer Drug Targets 16: 71-8 [PMID:26563883]

5. Dhers L, Ducassou L, Boucher JL and Mansuy D. (2017) Cytochrome P450 2U1, a very peculiar member of the human P450s family. Cell Mol Life Sci 74: 1859-1869 [PMID:28083596]

6. Fekry MI, Xiao Y, Berg JZ and Guengerich FP. (2019) A Role for the Orphan Human Cytochrome P450 2S1 in Polyunsaturated Fatty Acid $\omega$-1 Hydroxylation Using an Untargeted Metabolomic Approach. Drug Metab Dispos 47: 1325-1332 [PMID:31511258]

7. Pan Y and Ong EC. (2017) Cytochrome P450 2W1 (CYP2W1) - ready for use as the biomarker and drug target for cancer? Xenobiotica 47: 923-932 [PMID:27690753]

8. Siller M, Goyal S, Yoshimoto FK, Xiao Y, Wei S and Guengerich FP. (2014) Oxidation of endogenous $\mathrm{N}$-arachidonoylserotonin by human cytochrome P450 2U1.J Biol Chem 289: 1047687 [PMID:24563460]

9. Xu S, Ren Z, Wang Y, Ding X and Jiang Y. (2014) Preferential expression of cytochrome CYP CYP2R1 but not CYP1B1 in human cord blood hematopoietic stem and progenitor cells. Acta Pharm Sin B 4: 464-9 [PMID:26579418]

10. Yan P, Eng OC and Yu CJ. (2018) A Review on the Expression and Metabolic Features of Orphan Human Cytochrome P450 2S1 (CYP2S1). Curr Drug Metab 19: 917-929 [PMID:29804525] 